\title{
The Hemoglobin Levels and Hematocrit Decrement is less in Severe Preeclampsia Patients Undergoing Caesarean Section with B-Lynch as Prophylaxis
}

\author{
Perbandingan Penurunan Kadar Hemoglobin dan Nilai Hematokrit \\ Pascaseksio Sesarea dengan dan tanpa Profilaksis B-Lynch \\ pada Pasien Preeklampsia Berat
}

\author{
Ahmad Parwis, Anita D. Anwar, Setyorini Irianti \\ Department of Obstetrics and Gynecology \\ Faculty of Medicine University of Padjadjaran/ \\ Dr. Hasan Sadikin Hospital \\ Bandung
}

\begin{abstract}
Objective: To analyze the differences between the reduction in hemoglobin and hematocrit level in severe preeclampsia patients who have had Caesarean section with and without B-Lynch prophylaxis.

Method: The design of the study was an experimental analytic with Randomized Control Trial (RCT). Thirty patients who came to Dr. Hasan Sadikin Hospital, Soreang Hospital, and Cibabat Hospital during 11 July - 25 September 2012 and met inclusion criteria were selected and divided into two groups. The first group were caesarean section with B-Lynch prophylaxis, the second one were without BLynch prophylaxis. The sample were taken with simple random sampling. Each patient were examined for hemoglobin and hematocrit level before and 6 hour after $\mathrm{C}$ section. The data was analyzed by t-test and Mann Whitney test.
\end{abstract}

Result: There were significant differences $(p<0.05)$ on the decrease of hemoglobin and hematocrit level between patient who were performed B-Lynch prophylaxis and those who were not $(7.98 \%$ vs $19.75 \% ; \mathrm{p}=0.001$ and $9.02 \%$ vs $18.28 \%, \mathrm{p}=0.013$, respectively).

Conclusion: The decreasing hemoglobin and hematocrit level before and 6 hour after $C$ section is less in patient with severe preeclampsia who had caesarean section with B-Lynch prophylaxis compared to cesarean section without B-Lynch prophylaxis.

[Indones J Obstet Gynecol 2013; 1-3: 139-44]

Keywords: B-Lynch, postpartum haemorrhage, preeclampsia

\section{Abstrak}

Tujuan: Menganalisis perbedaan penurunan kadar hemoglobin dan nilai hematokrit pada pasien preeklampsia berat yang dilakukan seksio sesarea dengan dan tanpa profilaksis B-Lynch.

Metode: Penelitian yang digunakan adalah eksperimental dengan rancangan Randomized Control Trial (RCT). Tiga puluh pasien preeklampsia berat yang datang ke RSUP Dr. Hasan Sadikin, RSUD Soreang dan RSUD Cibabat selama periode 11 Juli - 25 September 2012 dan telah memenuhi kriteria inklusi dibagi ke dalam 2 kelompok perlakuan yaitu seksio sesarea dengan profilaksis B-Lynch dan kelompok kontrol yaitu seksio sesarea tanpa profilaksis B-Lynch. Pengambilan sampel dengan metode acak sederhana, pada kedua kelompok perlakuan dilakukan pemeriksaan kadar hemoglobin dan nilai hematokrit sebelum operasi dan 6 jam pascaoperasi. Data yang diperoleh dianalisis dengan uji t dan uji Mann-Whitney.

Hasil: Terdapat perbedaan yang bermakna pada persentase penurunan hemoglobin antara pasien yang dilakukan profilaksis B-Lynch dengan yang tidak dilakukan profilaksis B-Lynch $(7,98 \%$ vs $19,75 \%$; $p=0,001$ ), Demikian pula persentase penurunan nilai hematokrit $(9,02 \%$ vs $18,28 \%, p=0,013)$.

Kesimpulan: Penurunan hemoglobin dan hematokrit sebelum operasi dengan 6 jam setelah operasi lebih sedikit pada pasien preeklampsia berat yang dilakukan seksio sesarea dan profilaksis B-Lynch dibanding dengan tanpa profilaksis B-Lynch.

[Maj Obstet Ginekol Indones 2013; 1-3: 139-44]

Kata kunci: B-Lynch, perdarahan pascasalin, preeklampsia

Correspondence: Ahmad Parwis, Faculty of Medicine University of Padjadjaran/Dr. Hasan Sadikin Hospital Bandung. Jln. Pasteur 38 Bandung. Telephone : 022-2032530/081397583945. Email: parwispulungan@yahoo.com

\section{INTRODUCTION}

Postpartum hemorrhagic is an emergency state in the field of obstetrics, which is one of the main cause for morbidity and mortality. ${ }^{1}$ Postpartum hemorrhagic can also cause persistent defect in form of loss of the uterus due to hysterectomy. ${ }^{1,2}$ Massive postpartum hemorrhagic can lead to necrosis of the anterior pituitary lobe causing Sheehan's Syndrome. The main causes of hemorrhagic are postpartum atonic uterine and the placental retention. ${ }^{1}$ Complications arise depending on the amount of blood loss, the state of maternal health before hemorrhagic and the accuracy and also the speed from the medical caregiver. ${ }^{2}$ Complications from hemorrhagic and anemia postpartum will be more severe if it occurs on the underlying anemic state. ${ }^{1,2}$ Determining the amount of bleeding that comes out is very difficult and mostly is under es- 
timated. $^{2,3}$ In Healthy women, $1000 \mathrm{ml}$ of blood loss can be tolerated, but for women with poor health will lead to prolonged complications. ${ }^{1-3}$

Postpartum hemorrhagic cannot always be predicted, many of the risk factors associated with postpartum hemorrhagic such as: the use of tocolytics, the use magnesium sulphate in preeclampsia, age above 35 years, body mass index above 30 , multiple pregnancy, previous history of bleeding at delivery, macrosomia, hydramnios, prolonged labor, and delivery by caesarean section. ${ }^{2,3}$

Caesarean section is one of the risk factors for postpartum hemorrhagic. ${ }^{3-5}$ In a cohort study the number of hysterectomy supravaginalis was 186 $(0.5 \%)$ out of 39,244 deliveries by caesarean section. ${ }^{4}$

In Dr. Hasan Sadikin General Hospital, based on the annual report from 2011, the incidence of supravaginalis hysterectomy were $26(2.9 \%)$ out of 876 deliveries by Caesarean section and 8 (30.8\%) of them suffered severe preeclampsia. In the same year there were 4 cases of death due to delay in treatment of bleeding due to postpartum atonic uterine. $^{6}$

B-Lynch technique was introduced 14 years ago, and the use of this uterine compression technique is increasingly popular. ${ }^{7-9}$ B-Lynch technique can be performed at any time if patient have the risk of postpartum hemorrhagic. 7,8 But employment of B-Lynch technique after hemorrhagic due to uterine atonic still risking maternal morbidity such as anemia, fatigue, depression, and the risk of massive postpartum hemorrhagic can cause necrosis of the anterior lobe hipofise. ${ }^{10,11}$

Based on research by Kayem G of 211 patients who underwent B-Lynch, 25\% of cases required blood transfusion and hysterectomy. ${ }^{8}$ Failure of uterine conservation is due to delay in the employment of B-Lynch. ${ }^{8}$

Research by E Kalu in 2002, managed to give B-Lynch prophylaxis to prevent postpartum hemorrhagic in laboring women with triplet pregnancies and heart failure. ${ }^{12}$ Vachani, in India performed research regarding B-Lynch prophylaxis in patients with the risk of postpartum hemorrhagic, performed emergency Caesarean section. Based on this study, effective prophylactic B-Lynch was suggested as an easy, fast, inexpensive and safe method in preventing postpartum hemorrhagic in patients with bleeding risk factors underwent caesarean section. ${ }^{10,11}$

\section{METHOD}

The study design was experimental, analytical Randomized Control Trial (RCT) group of severe preeclampsia patients with inclusion criteria: having indication to performed Caesarean section based on obstetric indications and prophylaxis of B-Lynch by using chromic catgut thread no 2 and a control group of patients with the same criteria but did not underwent prophylactic B-Lynch. Severe preeclampsia patient without HELLP syndrome and hemoglobin level $>10 \mathrm{~g} / \mathrm{dl}$, received treatment 4 grams (loading dose) $20 \% \mathrm{MgSO}_{4}$, and 10 grams $20 \% \mathrm{MgSO}_{4}$, (maintenance dose) according to caesarean section therapy protocol department of obstetrics and gynecology Dr. Hasan Sadikin General Hospital. Patients was performed Caesarean section with regional anesthesia without sedation in Dr. Hasan Sadikin General Hospital and its Hospital networks (Cibabat Hospitals, Soreang Hospitals).

Patients will be dropped out in the event of uterine atonic which forced the doctor in doing B-Lynch or if any abnormalities in the uterus was found, or baby weighted over 4,000 grams and require immediate transfusion within the first 6 hours postoperatively. Routine blood tests was performed in sequences to assess changes in hemoglobin and hematocrit level.

Statistical analysis performed to asses the difference of hemoglobin and hematocrit decrement in patients who underwent B-Lynch. Analysis was performed using an unpaired $t$ test for the normally distributed data, and using Mann Whitney test statistic if the data is not normally distributed.

\section{RESULT}

Table 1. Characteristics of the Subject in the Two Groups

\begin{tabular}{|c|c|c|c|}
\hline \multirow{2}{*}{ Variables } & \multicolumn{2}{|c|}{ Research Group } & \multirow{2}{*}{$\begin{array}{c}\text { Significance } \\
\text { p }\end{array}$} \\
\hline & $\begin{array}{l}\text { Prophylaxis B-Lynch } \\
\text { (n=15) }\end{array}$ & $\begin{array}{l}\text { Without Prophylaxis } \\
\text { B-Lynch }(\mathrm{n}=15)\end{array}$ & \\
\hline $\begin{array}{l}\text { Age } \\
\quad<20 \text { years } \\
20-35 \text { years } \\
>35 \text { years }\end{array}$ & $\begin{array}{l}2(13.33 \%) \\
7(46.66 \%) \\
6(40 \%)\end{array}$ & $\begin{array}{l}1(6.66 \%) \\
9(60 \%) \\
5(33.33 \%)\end{array}$ & 0.714 \\
\hline $\begin{array}{l}\text { BMI } \\
\quad \leq 19.8 \\
19.9-26\end{array}$ & $\begin{array}{c}1(6.66 \%) \\
14(93.33 \%)\end{array}$ & $\begin{array}{c}0(0 \%) \\
15(100 \%)\end{array}$ & 1.000 \\
\hline $\begin{array}{c}\text { Parity } \\
1 \\
2-4 \\
\geq 5\end{array}$ & $\begin{array}{l}5(33.33 \%) \\
9(60 \%) \\
1(6.66 \%)\end{array}$ & $\begin{array}{l}7(46.66 \%) \\
6(40 \%) \\
2(13.33 \%)\end{array}$ & 0.429 \\
\hline $\begin{array}{c}\text { Gestational age } \\
34-<37 \text { weeks } \\
37-<42 \text { weeks }\end{array}$ & $\begin{array}{l}7(46.66 \%) \\
8(53.33 \%)\end{array}$ & $\begin{array}{l}8(53.33 \%) \\
7(46.66 \%)\end{array}$ & 0.715 \\
\hline $\begin{array}{l}\text { Baby Weight } \\
\quad<2500 \mathrm{~g} \\
2500-<4000 \mathrm{~g}\end{array}$ & $\begin{array}{r}3(20 \%) \\
12(80 \%)\end{array}$ & $\begin{array}{r}3(20 \%) \\
12(80 \%)\end{array}$ & 1.000 \\
\hline
\end{tabular}

Chi-Square test. $p$ significant if $p<0.05$ 
Table 1 shows the characteristics of the subjects in terms of maternal age, body mass index, parity, gestational age and infant weight, there were no significant differences between subject in both study groups. Based on the homogeneity of the data above, the three groups above is comparable.

Table 2 shows that the prophylactic B-Lynch reduce the amount of bleeding. This play role in the decrement of hemoglobin level for the group where prophylactic B-Lynch was performed rather than the group that did not underwent prophylactic B-Lynch. Decrement in hemoglobin levels was statistically significant.

Table 2. Comparison of Hemoglobin Levels in the Two Groups

\begin{tabular}{|c|c|c|c|}
\hline \multirow{2}{*}{ Variables } & \multicolumn{2}{|c|}{ Hemoglobin } & \multirow[b]{2}{*}{$\underset{\mathbf{p}}{\text { Value }}$} \\
\hline & $\begin{array}{l}\text { Preoperative } \\
\text { (n=15) }\end{array}$ & $\begin{array}{l}\text { Postoperative } \\
(n=15)\end{array}$ & \\
\hline Treatment & Mean (SD) & Mean (SD) & \\
\hline B-Lynch & $12.45(0.99)$ & $11.43(0.91)$ & 0.014 \\
\hline Without B-Lynch & $12.83(1.28)$ & $10.27(1.45)$ & \\
\hline
\end{tabular}

Unpaired T test. $\quad p$ significant if $p p<0.05$

Table 3 shows that the prophylactic B-Lynch decrease the amount of bleeding. A decrement in hematocrit level for the prophylaxis group which BLynch was performed was smaller, compared to those who did not under went prophylactic BLynch. Decrement in hematocrit value was statistically significant.

Table 3. Comparison of Hematocrit Levels in the Two Groups

\begin{tabular}{lccc}
\hline \hline \multirow{2}{*}{ Variables } & \multicolumn{2}{c}{ Hematocrit } & Value \\
\cline { 2 - 3 } & $\begin{array}{c}\text { Preoperative } \\
(\mathbf{n = 1 5 )}\end{array}$ & $\begin{array}{c}\text { Postoperative } \\
(\mathbf{n}=\mathbf{1 5})\end{array}$ & $\mathbf{p}$ \\
\hline Treatment & Mean (SD) & Mean (SD) & \\
B-Lynch & $38.13(3.13)$ & $34.53(2.13)$ & 0.006 \\
Without B-Lynch & $37.6(3.69)$ & $30.60(4.37)$ & \\
\hline \hline Mann Whitney test. & p significant if p p<0.05 &
\end{tabular}

\section{DISCUSSION}

Characteristics of the studied subjects are maternal age, gestational age, parity, body mass index, all of them did not found a significant difference, and so it is comparable.

Table 1 shows the demographics of the study subjects maternal age, body mass index, parity, gestational age and infant's weight. From the table above, maternal age in both study groups mostly in the age group of 20-35 years, consist of 7 people (46.66\%) in the B-Lynch prophylaxis group and 9 $(60 \%)$ in the group non-prophylactic B-Lynch. In the age group less than 20 years, there are 2 people $(13.33 \%)$ underwent prophylactic B-Lynch and 1 $(6.66 \%)$ in the group non-prophylactic B-Lynch. Age characteristic over than 35 years earned as many as 6 people $(40 \%)$ in the prophylactic BLynch and 5 (33.33\%) in the group non-prophylactic B-Lynch. Statistic analysis obtained $p$ value 0.714 , value of $p$ greater than 0.05 (non significant). Based on the characteristics of the age in this group was obtained a higher risk of postpartum hemorrhagic in the age group less than 20 years old and over 35 years old.

Based on Table 1, body mass index is divided into $\mathrm{BMI} \leq 19.8$ is 1 person $(6.66 \%)$ in the prophylaxis of B-Lynch. BMI 19.9 to 26 consist of 14 people (93.33\%) B-Lynch prophylaxis group and 15 people $(100 \%)$ in the group non-prophylactic BLynch. We did not found BMI $\geq 26$ in both study groups. Statistic analysis obtained $p$ value 0,309 by the value of $\mathrm{p}$ greater than 0.05 (not significant) indicating no significant difference was found between the two studygroup. Based on the IMT, both groups are not at higher risk for pospartum hemorrhagic.

Parity classification in this study is that the parity between 2-4 are 9 people $(60 \%)$ in the group underwent prophylatic B-Lynch and $6(40 \%)$ in the group that did not underwent prophylactic BLynch, parity 1 is 5 people $(33.33 \%$ ) in the prophylatic B-Lynch group and 7 (46.66\%) in the group that did not underwent prophylactic BLynch. Parity 5 or more by 1 people $(6.66 \%)$ in the prophylatic group and the 2 people $(13.33 \%)$ in the group that did not do underwent prophylactic B-Lynch. Analysis statistic obtained p-value $=0.429$, $\mathrm{p}$ value is greater than 0.05 (non significant) indicating, there is no significant difference found between the two study group. Parity 5 or more, increasing risk factors for postpartum hemorrhagic.

Gestational age divided into gestational age 37 $<42$ weeks was found in 8 people $(53.33 \%)$ in the prophylatic B-Lynch and 7 (46.66\%) in the group non-prophylactic B-Lynch, gestational age $34-<37$ weeks by 7 people $(46.6 \%)$ in the prophylaxis of B-Lynch group and 8 (53.33\%) in the non-prophylactic B-Lynch group. Among the test subjects ges- 
tational age $\geq 42$ weeks is none, analysis statistic obtained $\mathrm{p}$-value $=0.715, \mathrm{p}$ value obtained is greater than 0.05 (non significant) indicating there is no significant difference was found between the two study group.

Baby's weight at birth were divided into 3 groups, weight infants less than 2500 grams, the baby weight $2500-<4000$ grams, and the baby's weight $\geq 4000$ grams. In this research, the distribution was same in both study groups, which weights less than 2500 grams each 3 people (20\%) and weight up to 2500 infants $<4000$ grams each 12 people $(80 \%)$. And we did not get any baby weighted $\geq 4000$ grams. Statistic analysis obtained $\mathrm{p}$ value $=1.000$.

Table 2 presents the average hemoglobin level before surgery in patients who underwent prophylactic B-Lynch = 12.45 (0.99) and the mean hemoglobin levels among group who did not underwent B-Lynch was 12.83 (1.28). In accordance with the proposed inclusion criteria were a hemoglobin level $>10 \mathrm{~g} / \mathrm{dl}$, this was done to get rid of the bias effect of anemia due to postpartum hemorrhagic, based on the previous research that $\mathrm{Hb}$ level $>10$ did not give significant effect on the occurrence of postpartum hemorrhagic. The average hemoglobin levels after surgery in the group that carried out prophylactic B-Lynch was 11.43 (0.91) and the group that did not underwent prophylactic BLynch was 10.27 (1.45). The average hemoglobin levels in patients who underwent prophylactic BLynch is higher than the group that did not underwent prophylactic B-Lynch. Based on $t$ value from $t$ test $p=0.014$ and this value is less than 0.05 so the difference is significant.

From the research data we obtained there is less hemoglobin loss in patients who underwent prophylactic B-Lynch from 0 to $2.6 \mathrm{~g} / \mathrm{dl}$ with average $1.026 \mathrm{~g} / \mathrm{dl}$. Calculation of hemoglobin without other parameters are considered less precise. The most substantial decrease in hemoglobin was 2.6 $\mathrm{g} / \mathrm{dl}$, the risk factors that can be analyzed at this patient is severe preeclampsia, having $20 \% \mathrm{MgSO}_{4}$, and emergency Caesarean section. In patients who do not underwent prophylactic B-Lynch we found hemoglobin decrement between $0.7 \mathrm{~g} / \mathrm{dl}$ to 5.3 $\mathrm{g} / \mathrm{dl}$ with an average of $2.56 \mathrm{~g} / \mathrm{dl}$, there was 1 case of decrease in hemoglobin $>4 \mathrm{~g} / \mathrm{dl}$ with an age characteristic more than 35 years, parity more than 4, patients received additional uterotonic treatment and observation are more stringent.
The calculation of the hematocrit value in the study group are presented in Table 3 . the average value of initial hematocrit in both studies, 38.13\% (3.13) in the group that carried out prophylactic B-Lynch and 37.6\% (3.69) in the group that did not underwent prophylactic B-Lynch. Hematocrit values after 6 hours post operation are 34.53\% (2.13) in the group that carried out prophylactic B-Lynch and $30.60 \%$ (4.37) in the group that did not underwent prophylactic B-Lynch. Based on the MannWhitney test, $\mathrm{P}$ value obtained $=0.006$, this value is less than 0.05 so the difference is significant.

From the research data, we obtained decrement hematocrit is less, in patients who underwent prophylactic B-Lynch from 0 to $11 \%$, with an average of $3.6 \%$. There is one case of hematocrit decrement of $11 \%$ but hemoglobin decrement was $2.6 \mathrm{~g} / \mathrm{dl}$ in without any evidence of active bleeding so that only observation was done. In patients who did not underwent prophylactic B-Lynch, decreased hematocrit is ranged from 1 to $14 \%$ with an average of $7 \%$, the decrement was more than patient who underwent B-Lynch. There were 5 cases of decrement hematocrit greater than $10 \%$ with the characteristics of patients aged over 35 years, this findings is in accordance with previous studies that age over 35 are risk factors for increasing risk of bleeding in postpartum hemorrhagic about 3 times higher. Based on the previous explanation, hematocrit decrement more than $10 \%$ is categorized into bleeding after Caesarean section, in this case patients received additional uterotonic drugs and stricter observation.

Characteristics obtained from the patients who performed the B-Lynch having a reduced amount of hemoglobin mostly happened in patients with more than 35 years of age, and parity more than 4. Based on the results of previous studies for more than 35 years of age have 1.41 odds ratio, body mass index over 30 have odd ratio 1.50 , severe preeclampsia have odds ratio 1.50 , and emergency Caesarean section have odds ratio 3.09, each of this point, increasing risk factors for greater decrement in hemoglobin and hematocrit.

In the group that did not underwent B-Lynch, the largest decrement of hemoglobin and hematocrit found in patients aged over 35 years, and parity more than 4 . This pointed out greater risk factor contributing in decrement of hemoglobin and hematocrit. In this research, the average percentage decrement in hemoglobin was $7.98 \%$ in 
the prophylactic group performed B-Lynch and $19.75 \%$ in the group that did not underwent prophylactic B-Lynch. Percentage reduction in mean hematocrit values were $9.02 \%$ in the prophylatic group performed B-Lynch and $18.28 \%$ in the group that did underwent prophylactic B-Lynch. Based on Schmit's research, preeclampsia increases the risk of bleeding by 1.5 times. ${ }^{13}$ Based from the Eskold's research, postpartum hemorrhagic is 2 times higher in preeclampsia patient than normal blood pressure patient. ${ }^{14,15}$ In this research, decrement in hemoglobin and hematocrit is about 2 times more lower in patients who underwent B-Lynch prophylaxis compared with those who did not underwent prophylactic B-Lynch. Patients with bleeding or a decrease in hemoglobin and hematocrit values on this research can still be treated by administering uterotonic, so no need for B-Lynch procedure or hysterectomy. ${ }^{14}$

Patients with preeclampsia who received $\mathrm{MgSO}_{4}$ therapy is a risk factor for having atonyuterine, because it has the tocolytic effect of $\mathrm{MgSO}_{4} \cdot{ }^{16-19} \mathrm{Mag}$ nesium sulfate has two action, as the tocolytic drugs by suppressing nerve transmission directly to the myometrium and the effect on myometrial cells. ${ }^{16-17}$ First, an increase in magnesium levels decreasing release acethylcoline by motor and plate at the neuromuscular junction so that Magnesium prevents calcium influx to neurons and effectively block the nerve transmission. ${ }^{16-17}$ Second, the effect of magnesium to calcium antagonists at the cellular level and extracelular. ${ }^{16-18}$

Physiologically, within a few minutes after birth, there was a strong uterine contractions and reduced intrauterine surface tention which causes the separation of the placenta from the maternal decidua implantation. ${ }^{2}$ In normal circumstances, the amount of bleeding is limited by the contraction of myometrial fibers because the blood vessels which supply the placental sinuses are surrounded by smooth muscle fibers and muscle fibers will be depressed if it contracting, so that the blood supply to the sinus is decreasing. $1,2,20$

The process of postpartum hemorrhagic stop, primarily occurs mechanically, the muscles of the uterus will contract strongly after induced by the hormones. Myometrium contract so strongly after the baby is born and the placenta is "born". Muscle fibers will retracted and will reduce the volume of uterine bleeding postpartum. ${ }^{2,7}$ Bleeding control was done due to the contraction and retracted fi- bers that crossing around the myometrium. Myometrial contraction will push the spiral arteries and veins, known as Living ligatures. ${ }^{2}$ If uterine contractions disrupted due to the influence of $\mathrm{MgSO}_{4}$ or because of other risk factors, the Living ligatures is not happening, then this is where we expect BLynch mechanism to compress uterine and stop the bleeding. ${ }^{10}$

In accordance with the study conducted by Vachani during 2007, B-Lynch provide an effective prophylaxis to prevent postpartum hemorrhagic, with a decrease in mean hemoglobin $0.81 \mathrm{gr} / \mathrm{dl}^{9}{ }^{9}$ Results obtained in this study is the decrement in hemoglobin levels is greater which is $1.02 \mathrm{~g} / \mathrm{dl}$, but the difference was, in this study is in the amount of the sample, using sample size of 30 who were divided into 2 groups: 15 samples each, and the differences in the research inclusion criteria.

\section{CONCLUSION}

Decrement in hemoglobin and hematocrit level before surgery up to 6 hours after surgery in patients with severe preeclampsia who performed Caesarean section and the B-Lynch prophylaxis is better, compared with group who did not performed prophylaxis B-Lynch.

\section{REFERENCES}

1. The Prevention and Management of Postpartum Haemorrhage: Report of Technical Working Group, Geneva 2000.

2. Combs CA, Murphy EL, Laros RK. Factors associated with postpartum hemorrhage with vaginal birth. Obstet Gynecol 2011; 77: 69-76.

3. Wiknjosastro, Buku Ilmu Kebidanan edisi Ketiga Cetakan Ketujuh. Yayasan Bina Pustaka Sarwono Prawiroharjo. Jakarta; 2005.

4. Shellhans C, Gilbert S, Landon M, Varner M, Leveno K, Hauth J. The Frequency and Complication Rates of Hysterectomy Accompanying Cesarean Delivery. Obstet Gynaecol. 2009; 114: 224-9.

5. Sarah G, Ekwalanga P, Roberts G, Birch C, Rosengarten A. Peripartum Hysterectomy 1999 to 2006. Am College Obstet Gynecol 2008; 111:732-8.

6. Tjahjadi D, Hidayat D, editors. Laporan tahunan 2011 Departemen Obstetri dan Ginekologi RSUP Dr. Hasan Sadikin/ FK UNPAD. Bandung: Departemen OBGIN; 2011.

7. Vachhani M, Virkud A. Prophylactic B-Lynch Suture During Emergency Caesarean Section In Women At High Risk of Uterine Atony: A Pilot Study. Internet J Gynecol Obstet. 2007.

8. Kayem G. Uterine Compression Sutures for the Management of Severe Postpartum Hemorrhage The American College of Obstetricians and Gynecologists, Lippincott, Williams \& Wilkins. 2011. 
9. Price N, B-Lynch C. Technical description of the B-Lynch brace suture for treatment of massive postpartum haemorrhage and review of published cases. Int J Fertil Womens Med 2005; 50: 148-63.

10. Michelle A. Kominiarek, MD, Sarah J. Kilpatrick M. Postpartum Hemorrhage: A Recurring Pregnancy Complication, Department of Obstetrics and Gynecology, Indiana University School of Medicine, Indianapolis, IN Semin Perinatol, 2007, 31: 159-66.

11. Andrew C, Edward L, Murphy, Russel K. Factors Associated With Hemorrhage in Cesarean Deliveries. Br J Obstet Gynaecol 2001; 77.

12. Kalu E, Wayne C, Croucher C, Findley I, Manyonda I. Triplet pregnancy in a Jehovah's Witness; recombination human eritropoietin and iron supplementation for minimising the risk of excessive blood loss. Br J Obstet Gynaecol 2002; 109: 723-5

13. Schmit MD. Preeclamsi Increase The Risk of Postpartum Hemorrhage, Leiden University Medical Center, 2012.

14. Chad A. Grotegut, Michael J. Paglia M, Lauren N. Johnson, M. et al, Oxytocin exposure during labor among women with postpartum hemorrhage secondary to uterine atony. Am J Obstet Gynecol 2011; 204: 56.e1-6.
15. B-Lynch C, Coker A, Lawal AH, Abu J, Cowen MJ. The BLynch surgical technique for the control of massive postpartum haemorrhage: an alternative to hysterectomy. Five cases reported. Br J Obstet Gynaecol 2002; 104: 372-5.

16. Sibai BM, Graham JM, Mc Cubbin JH. A comparation of intravenous and intramuscular magnesium sulphate regimen in preeclampsia. Am J Obstet Gynecol 1999; 150: 728-33.

17. Grether JK, Hoogstrate J, Selvin S, Nelson KB. Magnesium sulfate tocolys and risk of neonatal death. Am J Obstet Gynecol 1999; 178: 1-6.

18. Hutchinson HT, Nichols MM, Kuhn CR, Vasicka A. Effects of magnesium sulfate on uterine contractility, intra uterin fetus and infant. Am J Obstet Gynecol 1994; 88: 747-57.

19. Dudley D, Gagnon D. Long term tocolysis with intravenous magnesium sulfate. Obstet Gynecol 1999; 73: 373-8.

20. Clark SL, Yeh SY, Phelan JP, Bruce S, Paul RH. Emergency hysterectomy for obstetric hemorrhage. Obstet Gynecol 2000; 64: 376-80. 